OLENA YATSENKO,

National Pedagogical Dragomanov University (Kyiv, Ukraine)

e-mail: yatsenkood@gmail.com,ORCID 0000-0003-0584-933X

\title{
HUMAN IN THE WORLD OF TECHNOLOGIES: ATTEMPT TO CONCEPTUALIZE A NEW ONTOLOGY
}

The article is devoted to the philosophical analysis of the phenomenon of technology and its influence to the content of modern socioculture. Based on the tradition of interpreting the phenomenon of technology as an explication of the content and structure of knowledge, the algorithm of effective activity and interaction, the author argues that the development of technology is not identical to increasing the number of tools and mechanisms, but means, above all, a simple and effective model of communication and social cooperation, which causes scientific and technological progress. It is argued that technology is the cement of modern culture, the channel of interaction between different levels of architecture of modern civilization. The understanding of the actual ontology of the technocratic standard as a space of pure freedom, purity of metaphysics is consistently substantiated, and therefore it is conceptualized that technology is the realization or materialization of possibility. It is proved that the metaphysical category of essence is replaced by the principle of functionality in the space of virtuality in the modern information society. The author argues that the development of virtual reality technologies is not the cause of such processes, but rather a natural consequence of history as the progress of human freedom. The idea of parity of actual and potential in the worldview orientations of the inhabitant of virtual space is substantiated, and it's creates a distorted focus of perception of everyday life as vague and meaningless. Accordingly, virtual reality changes the predications of its own expediency: from the purpose of sublimation of irrational impulses to the production of rationality of a new emotionalaffective variety, the criterion of which is fair to consider the metrics of public attention and publicity. The author argues that given the understanding of culture as a strategy of human survival, the issue of education is especially important not only as the acquisition of certain competencies, but also as a fundamental "experience of the possible."

Key word: ontology; culture; subjectivity; technique; technology; sociality; virtual.

\section{Introduction}

Technique and technology have existed since human civilization. Human is not just able to adapt to the environment, but can also change the world according to his own order. In March 2014, the World Health Organization reported that about 7 million people died in 2012 (WHO, 2014) accounting for eight of the world's total deaths from air pollution. But this is not the only result caused by environmental pollution. The consequences of human impact on nature are so huge and irreversible that the solution may seem to create a new, virtual reality. The number of Internet users in January 2020 was more than 4702202000 people $^{1}$. One third of the world's population spends a third of their free time online. Families spend an average of only eight hours a week together, on weekends at best two hours and twenty minutes devoted to communication between family members, during the week the amount of this time is reduced to an average of only 36 minutes a day (Mccann, 2013). So, the problem of subjectivity, society and communication is growing rapidly and arouses the greatest interest in the problem of

${ }^{1}$ Internet lives states/. Retrieved from http://www.internetlivestats.com/internet-users/

СХІД Том 1 (1) січень-лютий 2021 р. philosophical justification of technology and its impact on human and society.

\section{Research methods}

Technology is the cement of modern culture, the channel of interaction between different levels of architecture of modern civilization. Gernot Böhme (2008) singled out the problem of technology from four main paradigms. The ontological paradigm describes the principle of existence and cooperation of technology with other things, phenomena and around the world. The anthropological paradigm is focused on human as a subject of technological attitude, as well as on the opportunities and risks of this activity. The historical and philosophical paradigm provides the broadest context for understanding the problem of technology. The epistemological paradigm demonstrates the quality that passes to new knowledge, reveals the specifics of transformations in the dynamics of technology. The problem of measuring the ability of technology in the context of changes in the environment and human is very acute.

Proponents of "posthumanism" and "transhumanism" believe that the question of measurement is superfluous. Any changes in the human mind and body due to the needs of progress, and are methods of human adaptation 
to the changing world. Critics of these notions of boundless optimism point to the dangers of such beliefs. So, Francis Fukuyama warns against the destruction of the concept of social justice and possible social upheavals. Whether people become "born cyborgs" (Donna Haraway) or know the world in the coordinates of the "quasi-transcendental" (Derrida) is a challenge to modern culture and civilization.

The methodology of the phenomenon of technology is formulated in the following basic approaches.

1. Technology as a tool. This understanding reveals the ability of technology to transform reality. That is, technology is able to create a similarity of reality.

2. Technology as knowledge, value and creation. This research methodology reveals the rationality invested in the technique. And the phenomenon of technology not only creates new values, but significantly transforms the notion of value.

3. Technology as an element of different research paradigms. Distinguishing paradigms in the study of technology is useful for certain tasks. The problem of subjectivity is most clearly revealed in the anthropological paradigm of research. The historical and philosophical paradigm in the study of technology makes it possible to analyze different ways of human cooperation and different types of sociality. The epistemological paradigm focuses on communication based on general knowledge and worldview. The ontological paradigm focuses on the essence of the connection of different phenomena in a single system of reality.

Thus, the impact of technology on ontology is already obvious. The classical ontology is based on the assertion of dependence of the spiritual, the ideal world of the material, physical reality. The ontology of the technocratic standard is a space of pure freedom, the purity of metaphysics.

\section{Result and Discussions}

The concept of technology has a direct attribution in the concept of knowledge. Knowledge is possible as memory, including as historical memory. In fact, it is memory that is the basis of subjectivity as the stability of experience. Thus, the development of technique and technology is an explication of subjectivity. That is, the technique is necessary to meet the demands of subjectivity. If the progress of human culture is the progress of human freedom, then at the same time this process is an increase in the scale of human subjectivity. The subjectivity of the modern individual is oversaturated with content, and accordingly becomes de-personification. Therefore, there is a concept of an ideal and real communicative community. Having a large number of communication channels provided by technology, the individual is focused on their own subjectivity. On the other hand, technology significantly increases the space of freedom. Realities precede possibilities, and technology is the realization or materialization of possibilities. Thus, the coordinates of human existence change significantly. Technocratic civilization sets the parameters of subjectivity, sociality and communication. The new generation develops survival strategies in a new ontology.

In the space of virtuality, the experience of explication of sociality acquires qualitatively new features. Thus,
B. R Boriselli and others (2016) argue that the experience of virtual reality is a reason to evaluate as a process of communication between people mediated by computer systems. This experience is characterized by the use of various sensory stimulations. Based on the semiotic method, the authors explore the features of semantics, syntax and pragmatics of the virtual communicative space. The syntactic level is characterized by the determinism of the visual type of communication, semantics - a functional model of a virtual system, and pragmatics is the interaction of human and computer, which radically changes the role of the user and his functions. And S. Jones (1993) argues that virtual reality has long been a field of audio technology, so its content and forms of embodiment and implementation are closely linked to the type of discourse that dominates culture and history. Therefore, the author's conclusion is indisputable: the nature of virtual reality must be defined as an indirect and symbolic formation. The opposite position is taken by D. Gunkel (2000), who argues that virtual reality from the beginning of its existence was developed as a technology of image production and the corresponding communicative space, i. e. the space of communication mediated by images.

However, the question of how the problem of the sociality to connect to cyberspace is not exhaustive. Ulises Mejias (2001) calls communicative reality as a culturally specific conceptualization of social space that is created and shared by people through the act of communication. The development of virtual reality technologies allows us to look at the problem of communication in the social space from a different angle of perception and evaluation. Thus, virtuality illustrates the importance of communication in the processes of cognition and understanding of the world, has certain constitutive properties regarding the content of our knowledge. Accordingly, communicative reality is perceived as a way to assess to values and a procedure for conceptualizing our perceptions of the world.

The existence of society necessarily implies an act of transcendence. In the personal dimension, transcendence means overcoming the limits of existing being, striving for the Other, whatever the meaning of this concept (Absolute, human, symbol, thing). In historical perspective or retrospective, transcendence means an intelligible search for a semantic construction that explains the single logic of the set of events of the past and present. In the context of the culture the transcendence takes place as an explication of subjectivity in symbolic forms of expression and fixation of meaning. The philosophy of postmodernism is known to criticize the category of the transcendent. In research on the problem of social existence, postmodernism assesses transcendence in dimensions much more local than in previous epochs. Transcendence in their understanding is a speech-narrative structure of thinking, activity, evaluations, tastes, power, which unifies the community of individual subjects.

Virtual social space produces a specific way of existence and dimension of space and time, changes the specifics of perception and experience of these attributes of reality. It is quite natural that virtual space causes the formation of a specific symbolic field, the specificity of meaning-making and communication. This feature is not 
only in the way the virtual environment exists, but also in the new type of connection and interaction. Not mediated by materialization, the meaning and significance of virtual objects presupposes fundamentally different verification and falsification procedures. Just as virtual communities formally perform the same functions of socializing subjectivity as real groups. Note that real communities are related to the so-called materialized world. Something, that constitutes the essence of the social in content, closer to the virtual than to the material one. Indeed, social roles and hierarchies, habitus and rituals, institutions - all these phenomena cannot be reduced to objects of the material world in the usual sense, because their meaning is not revealed in sensory-empirical experience. However, the difference between real and virtual sociality is obvious: virtuality has no attribution in material, historical or ethnic, which gives grounds to assert its spontaneous or arbitrary nature of organization and explication.

The author of the theory of "cultural replicator" R. Dawkins introduces the methodology of cognitive sciences and neurophysiology to find answers to these questions. According to his concept, it is appropriate to localize cultural codes in the psychophysiological patterns of the community of subjects. As a result of the study, the scientist finds the physiological substrate of the cultural code, which takes place in the nervous system of the individual in the form of reflex arcs, which reflect the construction of stereotypical models of behavior and life. The presence of such structures in human neurophysiology as a carrier of a certain culture demonstrates the stability of spatio-temporal definitions. Therefore, it is logical to conclude that cultural codes can be phenomenologically identified, and accordingly, they have clear procedures for their objectification. The theories of R. Dawkins' "meme" and D. Rashkoff's "mediavirus" are based on the same logic. Therefore, "When they (social systems) arise, their appearance gives rise to a specific internal phenomenology, one in which the individual ontogenesis of all participants in organisms are components of a network of coontogenesis» (Maturana, 2001: 83). In other words, subjectivities that share common meanings, values, and behavioral algorithms have similar neurophysiological structures of consciousness, a kind of "software" that organizes the chaos and unpredictability of the empirical world. Such formations are the result of collective or cultural adaptation of mankind.

Using the methodology of another kind, the authors of the concept of social constructivism A. Schutz, N. Luhkmann, P. Berger come to similar conclusions. According to this approach, social reality is constructed in the space of intersubjective communication, which serves as a field of legitimization of meaning, value, action and organization. The dynamics of such procedures of legitimation and construction of social reality is studied by P. Bourdieu. For him, space and time are not empty abstractions, but the coordinates of social life. The complex of social relationships form is a social space, and the dynamics of their implementation is social time. The discreteness of social fields, or different codes of culture, is determined by the functioning of different habitus, stereotypical patterns of thinking and behavior. In other words, human adaptation is not a "habituation" to the world, but a at-habituation of the world to the social content of subjec- tivity. If the act of transcendence is personal, then the nature of transgression is social. The mechanism of transgression is to overcome the static procedures of meaning-making, to reorganize the fabric of social existence into new models of structuring, or to expand the boundaries of what is acceptable and customary. In the terminology of E. Levinas, this issue is revealed as a specific transition from subjectivity to intersubjectivity, the presence of the Other in the mental space of the modern individual. In other words, the transcendental subject of the classical age is transformed into transgressive forms of intersubjectivity, internalized forms of public opinion and cultural value. Thus, the meaninglessness of authentic substantial entities, including consciousness, is asserted, and their procedural nature and temporal dimensions of existence are emphasized. Functionality - this concept replaces the metaphysical category of essence in the space of virtuality of the contemporary information society. M. Cattell and others (2019) explore the problem of personal and social space in view of the development and spread of augmented reality technology. The authors explore the potential impact on the private sphere and the sphere of social interaction, the orientation of social relations and the distribution of social power in mixed reality and try to identify the range of potential threats and risks of negative effects of virtual augmented reality.

How appropriate is it to interpret communication in the space of virtuality in terms of traditional rationality? M. Kelemen and W. Smith (2001) criticize the libertarian rhetoric that takes place in the interpretations of "virtual communities". In their view, such theories are too far removed from the everyday practices of the common human. Therefore, the authors seek to define a virtual community based on the concept of "neo-tribe" M. Maffesoli. Thus, they believe that the Internet opens a new space where the will to live is expressed in a social and sustainable manner, and ethical and cultural stereotypes of conscious restriction of freedom of expression are ineffective. However, the development of virtual reality technologies is not the cause of such processes, but rather a natural consequence and embodiment of history as a progress of human freedom. Well-known thinkers and philosophers, such as U. Eco, M. McLuhan, and F. Fukuyama, prophesied the formation of a global world village as a consequence of the development of ICT. It is already possible to assert the substantial implementation of such predictions. And the global quarantine caused by the COVID-19 pandemic can rightly be considered a stress test of the effectiveness of such a communication and production model. And given the high chances of continuing both the pandemic and the restrictive measures associated with it, it is logical to assume that remote interaction techniques and technologies will be in increasing demand and development.

K. Ellison and C. Matthews (2010) argue that in modern thought there is a tradition of underestimating the importance of social networks in literary and political history. The authors argue that modern technologies of virtual communication are the embodiment of the way of communication and communication that took place since the XVIII century. It is from this century that the Enlightenment, which offers a culturally viable model of social cooperation supported by communication technologies, is 
gaining momentum. In addition, modern virtual reality technologies are effective in visualizing the historical and cultural context of the period being studied and researched. For example, the construction of threedimensional historical social spaces as a semester research project for students is a tactic for the effective use of modern technologies in the educational process. In addition, such research practices are useful in the broadest sense of the implementation of research on specific historical and cultural contexts, as well as to reflect on the current state of socio-culture.

A special problem of the current state of society is the phenomenon of everyday life in social networks. On the one hand, the postulation of some data on the content of existential experience in cyberspace acquires signs of social verification and legitimization. On the other hand, it creates a distorted focus of perception of everyday life as an event-intensive process. In other words, all significant events in a person's life are necessarily presented to the public, and the lack of such events against the background of a colorful ribbon of social networks is often the cause of psychological instability, neurosis and psychosis. Thus, quantitative indicators of data increase at all levels of possible analytics: from personal to planetary.

The position of Blay Whitby (1993) is balanced, who focuses on ethical issues that arise with the development of virtual reality technologies. And, even if we proceed from the comparative "novelty" of this technology, the issues that actualize its creation have a long history of their formation and discussion in reality as such. Thus, "In particular, VR could be used as a medium in which to explore the consequences of various types of behaviour. Theorists of behaviour could use this as an experimental technique to refine views on exactly how and why humans behave as they do. Theorists of morality could use them in a vast development of Danielson's work to explore the consequences of partial and widespread adoption of various ethical standards. Finally, and perhaps most importantly, the facility to have a reasonable simulation of another's experiences could refine the human ability to empathise. That is to say that the use of a VR to give, for example, the experience of crime from the point of view of criminal, victim, legislator and lawenforcer might give us all a technologically-based route to far greater moral sensibility" (Whitby, 1993: 28). Virtual reality gives its user the experience of presence, or activity, perceptually and meaningfully expressive, but conditional in terms of constant reality. Virtual space is a space of freedom, the apogee of freedom without consequences. However, this position is utopian and erroneous in nature. The expectation of positive results of such "education" due to negative experience in virtual reality is unreasonably optimistic. The consequence of such an experience is ambivalent: it can convince a person of the expediency and necessity of moral standards. Or it can be the other way around: a negative experience can be perceived by the subject as attractive and pleasant. And the possibility of such conclusions must also be taken into account.

An indisputable fact of large-scale impact on modern society is the understanding of cyberspace as communicative and public. Martin Ostwald, a well-known researcher of the history of Athens, argues that the development of the culture and democracy of ancient society is due to the tradition of free communication, freedom of thought and expression: "The Agora functioned as a center for information and free communication; it is for these reasons that it is associated with the political strengthening of Greece and democratic tendencies" (Galkin, 2004: 65). From the beginning of the information society, the metaphor of the Agora as a place of free exchange of opinions without censorship and dictatorship became a symbol of faith for the followers of freedom as a basic value of social development. Virtual reality at the first approximation fully corresponds to such a metaphor of space, freedom of thought and action. However, this belief seems increasingly naive according to the development of information and communication technologies. For example, suffice it to mention the Social Credit System in modern China, when any actions or activities in both virtual and real space are tightly controlled by public authorities and inevitably affect the course of later life.

Access to information does not mean the realization of the Enlightenment ideal of freedom through knowledge and education. On the contrary, the digital age postulates the totality of publicity and, consequently, the possibilities of control. D. J. Gunkel (2008) argues that the choice between red and blue pills in The Matrix is an illustration of the complex philosophical contradictions and structural conflicts associated with the information society and its formation. Such a binary code is a metaphor for our understanding of social reality. The author denies the "correct" choice of the red pill as the only acceptable revolutionary course of social transformation. He is convinced that it is possible to "blow up" the system by alternative methods of consistent criticism and conceptualization of the opposition.

Another way is suggested by Gladden J. Pappin (2012), who reflects on the problem of freedom in the context of virtual reality. While freedom has traditionally been postulated as an important value for both the personal and social dimensions of human life, the last century has placed opposite emphasis on this ethical issue. Significant influence in this transformation is played by the development of technologies, which are closely associated with the level of well-being of modern human. In addition, in the past, the content of the social mission of technology meant domination over nature, and in the present, virtual technology is actually a replacement for nature. The author calls postmodern irony an effective tool for counteracting the total impact of technology on consciousness. But is irony enough for modern human to survive in the technogenic digital world?

The problem of increasing the influence of technology in contemporary society is important for the whole spectrum of socio-cultural relations around the world. This is a question of psychological, social, political, economic, environmental nature, etc. The question is the origin of the new ontology, the principles of which are very vague. Accordingly, survival strategies are also vague. And the virtual reality produced by the development of technology already quite rightly has a predicate of sociality: subjects and their numerous images" (Lubsky, 2011: 23). Or "Virtual social reality as a potential social reality (ontological approach) and virtual social reality as its image or construct (epistemological approach) is a "replacement "of the actual constant social reality, i.e. such a social reality 
that has left "traces "and become the subject of cognitive interest" (Lubsky, 2011: 24). The essence of this "substitution" is to create a social space free from formalities, norms of regulation of behavior and assessments inherent in sustainable institutionalized forms of social life. In fact, virtual social reality is a space for free expression of subjectivity, which does not suffer from moral, ethical and value regulations. A.V. Lubsky proposes the following typology of virtual social reality: "Given the multiplicity of virtual social realities as a subjective "otherness" of social reality, we can distinguish such types of virtual social reality as imitation, imaginary and simulative" (Lubsky, 2011: 24). Imitation virtual reality embodies cognitive models developed by analogy with constant social reality. The constructions of its formation are not just similar to ordinary society and the processes of social interaction, but the reliability of this imitation allows replacing the constant reality. It is logical that the main tools for the production of imitative social reality are numerous mimic techniques of imitation of various socio-cultural experiences. The author expands the scope of application of the principle of mimesis from art and artistic creativity to research, experiments, economics and marketing, history and archeology, education and more. After all, simulated virtual reality is, first of all, a visualization of abstract theoretical positions. The author continues: "Imaginary social reality is a symbolic space that semantizes the external social world, giving images of the collective unconscious for the structures of the collective conscious, that is, pretending the irrational for the rational" (Lubsky, 2011: 27). In other words, imaginary social reality is ideas that take hold of the masses. The symbol in this case is necessary for the design and fixation of a supra-subjective meaning, universal for a particular community. Due to the effectiveness of symbolic forms, sociality acquires opportunities for fruitful realization: cognitive models, assessment techniques and algorithms of individual subjects are synchronized into a holistic social structure.

Simulated virtual reality does not involve imitation of constant reality, but the arbitrary production of possible worlds with any principles of organization and foundation. A.V. Lubsky notes the existing ambiguity of the term "simulacrum" in postmodernism. The so-called representative approach outlines the meaning of the concept as an imitation, forgery, ironic allusion to real existence. The unrepresentative approach fixes the absolute autonomy of the simulacrum; his apologist is essentially a sophist, whose sleeping mind begets a ghost. The purpose of simulated reality is to meet needs (from heuristic to erotic), emotional response and experience, "convenience" of self-identification. Virtual reality as such is a significant "agent of influence" in globalization and internationalization of the modern world: "It is the erosion of the social structure of society and the formation of new social groups, whose position depends on their attitude to intellectual and information property network virtual space. This is the reduction of social tensions due to the performance of virtual reality function of discharging negative social energy. This is the emergence of new opportunities for government and political participation through online virtual space (Bondarenko, 2007). Accordingly, all spheres of social life are undergoing changes: politics, economics, law, education, and so on. A person in the information space of virtual reality becomes an uncritical consumer of formal presentation, not internal content. We observe the implementation of the law of reverse action: virtual reality, the purpose of which is mainly to sublimate the impulses of the irrational, produces a new type of rationality, in which the energy of the emotional impulse is more important than logical-rational procedures to substantiate truth. The emphasis on procedurality and duration in the context of virtual reality is a hallmark of the modern information society, in which under the influence of globalization and technological growth, social time is accelerating and social space is shrinking. In contrast to the constant reality, which causes the current state of permanent anxiety (environmental and migration issues, hunger, epidemics and litter of the planet, local military confrontations and global terrorism, etc.), virtual reality offers a pleasant and safe environment for stay, expediency of which is faster in the process than as a result.

According to this state of modern socioculture, there are changes in the ways of social stratification. Thus, "Under the influence of virtual reality due to the involvement of human in his space through changing needs, motives and behaviors changes the social and professional structure of society, which forms new social strata: netocracy and consumerism" (Bondarenko, 2007: 127). T. A. Bondarenko describes this situation as follows: "Based on the analysis of socio-cultural processes occurring in modern society, it is observed that in the information society under the influence of virtual reality is the restructuring of the value system and the formation of new elements, the essence of which is related with the expression of human egocentric principles. In the general hierarchy of values, the value of quality of life, understood as the possibility of diversity of experiences and emotional accumulations, rises to a high level, and the pursuit of emotional experiences moves from the real world to the virtual world, which does not depend on social status transforms virtual reality into an absolutely necessary component of life" (Bondarenko, 2007: 128). All these arguments testify to the existing reduction in both interpersonal and social communications in general. And most importantly, this specificity of the social dimension of the virtual radically changes the subjectivity and techniques of its self-identification and explication. It is known that the sphere of moral and ethical and axiological components of human life is asserted on the basis of the internalization of social norms as recognition of the subjectivity of the Other. Virtual reality does not set limits for selfdiscovery and self-realization of subjectivity. As a result of the maximum of voluntarism in the space of virtuality, narcissistic, selfish motivations of subjectivity are growing. This situation is difficult to call accidental or unpredictable. It will be more reasonable to consider this specificity of virtual communication as a consequence of oversaturation of the information field of modern culture. If communication is closed in on itself, or "medium is the message", what is the opinion of Others worth? During the century of growth of the information field of culture, subjectivity risks losing its own identity, its own embodiment, disappearing in the flow of other people's voices. Therefore, such "selfish" positioning is a hypertrophied realization of the instinct of self-preservation, selfactualization, in which simply "being" is incomparably 
more important than "being someone" or "being in a certain way".

Virtual reality affects both individuals and society as a whole. The knowledge economy, digital money, the internationalization of education and the labor market, new communication models - all these phenomena of modern society affect the lives of people who are not even directly involved in the development or use of virtual reality. Visualization, or "clip" as a feature of contemporary culture, projects a format of communication in cyberspace, but at the same time, extends to the usual daily practices of human relations. Therefore, the indication of the technological and computer genesis of virtual reality, its significance and impact is not limited. It is appropriate to consider communication in the virtual mode as focusing on one's own subjectivity. The Other in such a focus of perception is not the goal, but the context of communication, i.e. as a stimulus, a stimulus for the disclosure in the dialogical process of their own intentions and meanings. This is network virtual communication: not the exchange of information in the traditional sense of communication, but the positioning of one's own message as a subject of attention by others. This principle is convincingly clarified by monetizing the number of audiences of content consumers in various online information platforms. Thus, G. de la Paz (2014) calls marketing a tool for changing reality, because due to its functions there is an opportunity to influence the motivational and value sphere of human life. And the rapid development of virtual reality technologies is increasing the scale of this impact to unpredictable horizons. Therefore, there is a strong need for the formation of marketing based on the ecological principle of interaction both within society and in relation to the natural environment.

\section{Conclusions}

The problem of the virtual in metaphysics was identified with potentiality and possibility. Modern development of digital technologies gives grounds to assert the parity of current and potential in worldviews. Given the understanding of culture as a strategy for human survival, the issue of education is especially important not only as the acquisition of certain competencies, but also as a fundamental "experience of the possible."

Virtual space is a field of expanding the boundaries of the functionality of its students. In other words, it is a human-sized and human-appropriate phenomenon of procedural co-creation of different subjectivities. And because subjectivity is a product of the social, dialogical nature of human, the digital virtual world provides supernatural opportunities for human community to communicate.

The ecology of relations presupposes sustainable and harmonious development. However, the analysis of constant reality gives grounds to assert the fact of growing social inequality both in the context of welfare and income of citizens of different regions and states, and in terms of access to social benefits such as medicine, education, social protection, freedom of expression. The impact of ICT on the growth of such inequality is difficult to call causal, more meaningful will be the position on the visualization, publicity of information about the existence of such inequality. However, cyberspace eliminates these differences. In it, subjectivity is not represented in the actual, real state, but in the desired, arbitrary. On the other hand, social networking can be useful in finding and connecting with like-minded people. And in a favorable social environment a person can implement the best project of himself. Therefore, the precedents of people's solidarity for the organization and coordination of collective activities, conditioned by a certain goal, are indicative and significant for the modern age. The so-called "communication revolution", backed by accelerating technological development, provides opportunities to create virtual communities to share knowledge around the world. However, the possibility does not mean the need for implementation, and the method of implementation may be unpredictable.

\section{REFERENCES}

Barricelli, B. R. \& Gadia, D., Rizzi, A., Marini, D. L. R. (2016) Semiotics of virtual reality as a communication process. Behaviour \& Information Technology. 35(11): Virtual reality in learning, collaboration and behaviour: content, systems, strategies, context designs: 879-896. https://doi.org/10.1080/0144929X.2016.1212092

Böhme, G. (2008). Invasive Technologie: Technikphilosophie und Technikkritik, Kusterdingen: Die Graue Edition.

Bondarenko, T. A. (2007). Virtualnaya realnost $v$ sovremennoy sotsialnoy situatsii. Dissertation of Doctor of Philosophy. Retrieved from https://www.dissercat.com/content/virtualnayarealnost-v-sovremennoi-sotsialnoi-situatsii. (In Russian)

De La Paz, Gabriel H. (2014). Modifying reality: marketing for the 22nd century. Journal of Global Scholars of Marketing Science. Bridging Asia and the World. 24 (3): Contribution of Philosophy to the Advancement of Marketing Thought: 246261. https://doi.org/10.1080/21639159.2014.911493

Ellison, K. \& Matthews, C. (2010). Virtual history: a socially networked pedagogy of enlightenment. Educational Re$\begin{array}{llll}\text { search. } & 52 & (3): & \text { 297-307. }\end{array}$ https://doi.org/10.1080/00131881.2010.504065

Galkin, A. I. (2004). Filosofskiye problemy virtualnoy realnosti. Izvestiya vysshikh uchebnykh zavedeniy. Severo-Kavkazskiy region. Obshchestvennyye nauki. (4): 3-9. Retrieved from https://cyberleninka.ru/article/n/filosofskie-problemyvirtualnoy-realnosti

Gunkel, D. (2000). Rethinking virtual reality: Simulation and the deconstruction of the image. Critical Studies in Media Communication. 17 (1): 45-62. https://doi.org/10.1080/15295030009388375

Gunkel, D. J. (2008). The matrix reconsidered. Thinking through binary logic in science fiction and social reality. Information, Communication \& Society. 11(6): Social Science Fiction: Thinking Beyond the Information Society. 816-830. https://doi.org/10.1080/13691180802005204

Jones, S. (1993). A sense of space: Virtual reality, authenticity and the aural. Critical Studies in Mass Communication. 10(3): 238-252. https://doi.org/10.1080/15295039309366866

Katell, Michael \& Dechesne, Francien \& Koops, Bert-Jaap \& Meessen, Paulus (2019). Seeing the whole picture: visualising socio-spatial power through augmented reality. Law, Innovation and Technology. 11 (2): 279-310. https://doi.org/10.1080/17579961.2019.1665800

Kelemen, M. \& Smith, W. (2001). Community and its 'virtual' promises: a critique of cyberlibertarian rhetoric. Information, Communication \& Society. 4 (3) : 370-387.

Lubsky, A. V. (2011). Sotsialnyye nauki i sotsialnaya realnost: $k$ voprosu o pogruzhenii $\mathrm{V}$ virtualnost. Nauchnaya mysl Kavkaza. (4): 19-29 (In Russian).

Maturana, U. (2001). Drevo poznaniya: Biologicheskiye korni chelovecheskogo ponimaniya. Moscow: Progress-Traditsiya. (In Russian) 
Mccann, Jaymi (2013, July, 14). No time for the family? You are not alone: Parents and children spend less than an hour with each other every day because of modern demands. MailOnline. URL: http://www.dailymail.co.uk/news/article2363193/No-time-family-You-Parents-children-s pend-hourday-modern-demands.html

Mejias, Ulises (2001). Sustainable communicational realities in the age of virtuality. Critical Studies in Media Communication. 18 (2) : 211-228. https://doi.org/10.1080/07393180128075
Pappin, G. J. (2012). In the Image of Technology: Modern Freedom, Virtual Reality. Perspectives on Political Science. 41 (4) : 207-215. https://doi.org/10.1080/10457097.2012.713266

Whitby, B. (1993). The virtual sky is not the limit: ethics in virtual reality. Intelligent Tutoring Media. 4 (1): 23-28. https://doi.org/10.1080/14626269309410069

WHO (2014, March, 25). 7 million premature deaths annually linked to air pollution. Retrieved from http://www.who.int/mediacentre/-news/releases/2014/air-pollution/en/

Олена Яценко,

Національний педагогічний університет ім. М. Драгоманова (м. Київ, Україна)

e-mail: yatsenkood@gmail.com,ORCID 0000-0003-0584-933X

\section{ЛЮДИНА В СВІТІ ТЕХНОЛОГІЙ: СПРОБА КОНЦЕПТУАЛІЗАЦІї НОВОЇОНТОЛОГІЇ}

Стаття присвячена фрілософському аналізу феномену техніки та їі впливу на зміст сучасної соціокультури. На основі традиції інтерпретації феномену техніки як експлікації змісту та структури знання, алгоритму ефективної діяльності та взаємодії, автор переконує в тому, що розвиток техніки та технології не тотожний примноженню кількості інструментів та агрегатів, а означає, насамперед, просту та ефективну модель комунікації та соціальної співпраці, що і спричиняє науково-технічний прогрес. Стверджується думка, що технологія - це цемент сучасної культури, канал взаємодії між різними рівнями архітектури сучасної цивілізації. Послідовно обґрунтовується розуміння актуальної онтології технократичного стандарту як простору чистої свободи, чистоти метафізики, і тому концептуалізовано, що техніка - це реалізація чи матеріалізація можливості. Доведено, що метафізична категорія сутності замінюється принципом функціональності у просторі віртуальності сучасного інформаційного суспільства. Автор аргументує, що розвиток технологій віртуальної реальності не є причиною таких процесів, а швидше закономірним наслідком історії як прогресу людської свободи. Обґрунтовується думка про паритетність актуального та потенційного в світоглядних орієнтаціях обивателя віртуального простору, що створює деформований фокус сприйняття буденності, як подієво невиразної та беззмістовної. Відповідно, віртуальна реальність змінює предикації власної доцільності: від призначення сублімації імпульсів ірраціонального до продукування раціональності нового емоційно-афективного гатунку, критерієм якої справедливо вважати метрику публічної уваги та розголосу. Автор доводить, що з огляду на розуміння культури як стратегії виживання людства, особливо важливим постає питання освіти не тільки як набуття певних компетентностей, але і як принципового “досвіду можливого”.

Ключові слова: онтологія; культура; суб’єктивність; техніка; технологія; соціальність; віртуальне.

(C) Olena Yatsenko

Надійшла до редакції: 09.12.2020

Прийнята до друку: 10.02.2021 